IZA DP No. 7424

Stature and Life-Time Labor Market Outcomes:

Accounting for Unobserved Differences

Petri Böckerman

Jari Vainiomäki

May 2013 


\title{
Stature and Life-Time Labor Market Outcomes: Accounting for Unobserved Differences
}

\author{
Petri Böckerman \\ Labour Institute for Economic Research \\ and IZA
}

Jari Vainiomäki

University of Tampere

Discussion Paper No. 7424

May 2013

IZA

P.O. Box 7240

53072 Bonn

Germany

Phone: +49-228-3894-0

Fax: +49-228-3894-180

E-mail: iza@iza.org

\begin{abstract}
Any opinions expressed here are those of the author(s) and not those of IZA. Research published in this series may include views on policy, but the institute itself takes no institutional policy positions. The IZA research network is committed to the IZA Guiding Principles of Research Integrity.

The Institute for the Study of Labor (IZA) in Bonn is a local and virtual international research center and a place of communication between science, politics and business. IZA is an independent nonprofit organization supported by Deutsche Post Foundation. The center is associated with the University of Bonn and offers a stimulating research environment through its international network, workshops and conferences, data service, project support, research visits and doctoral program. IZA engages in (i) original and internationally competitive research in all fields of labor economics, (ii) development of policy concepts, and (iii) dissemination of research results and concepts to the interested public.
\end{abstract}

IZA Discussion Papers often represent preliminary work and are circulated to encourage discussion. Citation of such a paper should account for its provisional character. A revised version may be available directly from the author. 


\title{
ABSTRACT
}

\section{Stature and Life-Time Labor Market Outcomes: Accounting for Unobserved Differences}

\begin{abstract}
We use twin data matched to register-based individual information on earnings and employment to examine the effect of height on life-time labor market outcomes. The use of twin data allows us to remove otherwise unobserved ability and other differences. The twin pair difference estimates from instrumental variables estimation for genetically identical twins reveal a significant height-wage premium for women but not for men. This result implies that cognitive ability explains the effect of height on life-time earnings for men. Additional findings using capital income as the outcome variable suggest that discrimination against short persons may play a role for women.
\end{abstract}

JEL Classification: I10, J23, J31

Keywords: height, weight, BMI, height premium, earnings, employment

Corresponding author:

Petri Böckerman

Labour Institute for Economic Research

Pitkänsillanranta 3A

00530 Helsinki

Finland

E-mail: petri.bockerman@labour.fi

\footnotetext{
*We would like to thank Jaakko Kaprio for access to the twin data and seminar participants at the Summer Meeting of Finnish Economists (Jyväskylä, 2012), the Labour Institute for Economic Research (Helsinki, 2012), the Finnish Economic Association (Åland, 2013), Ari Hyytinen, Pekka Ilmakunnas, Ohto Kanninen, Jaakko Kaprio and Edvard Johansson for helpful comments. Paul A. Dillingham has kindly checked the English language. This research has been financially supported by the Academy of Finland (project No. 127796).
} 


\section{Introduction}

Non-economic attributes, such as beauty and height, are widely rewarded in the labor market (Hamermesh and Biddle, 2004; Berggren et al., 2010; Guéguen, 2012). Several empirical studies document that taller individuals both receive higher wages and have better employment prospects (e.g., Sargent and Blanchflower, 1994; Judge et al., 2004; Persico et al., 2004; Case and Paxson, 2008; Hübler, 2009; Lundborg et al., 2013). ${ }^{1}$ Previous studies have used cross-sectional information on earnings, but they have not been able to account for unobserved ability effects in the height premium, which we can accomplish in this paper using twin data.

There are many potential explanations for the existence of the height premium. Some authors argue that the effect arises because height is associated with non-cognitive skills, such as social skills (Persico et al., 2004). ${ }^{2}$ Others maintain that cognitive skills are more important contributors to the height-wage premium (Case and Paxson, 2008). ${ }^{3}$ In particular, Case and Paxson (2008) argue that 30-50\% of the height premium can be attributed to cognitive ability measured in childhood and youth. Thus, taller persons receive higher wages because they have better cognitive ability, which is rewarded in the labor market. Lundborg et al. (2013) claim that the positive effect of height on earnings can be explained by the positive association between height and a person's physical capacity. ${ }^{4}$ They demonstrate that physical capacity explains $80 \%$ of the observed height premium for men. Furthermore, the height premium has also been explained by a correlation between height and authority (Lindqvist, 2012) or by the existence of discrimination against short persons in the labor market (e.g., Cinnirella and Winter, 2009).

We contribute to the debate on two frontiers by examining the effects of height on both earnings and employment using twin data. Using data on non-identical twins is effectively the 
same as controlling for sibling effects (the shared family environment). ${ }^{5}$ Additionally, monozygotic twins have the same genes, implying largely similar cognitive abilities ${ }^{6}$ and usually the same early life experiences and largely the same social contacts (non-cognitive skills). ${ }^{7}$ With data on genetically identical twins, we can remove the otherwise unobserved ability differences that constitute the most prominent explanation for the height premium according to Case and Paxson (2008). Furthermore, all other unobserved factors that closely correlate with genetics (shared family environment and shared interactions of genes and family) are removed for identical twins. Therefore, our contribution is to use twin data to control for differences between individuals in cognitive and non-cognitive skills in the height premium estimation. Previous research has used various test score results and other indicators to control for these factors. However, such tests are incomplete measures of the underlying traits that they measure. We argue that with the use of twin data we can more completely control for these unobserved traits.

Secondly, to examine the cumulative effects of height, we match the twin data to registerbased data on life-time labor market outcomes. This matching is important because previous studies on the height premium have almost exclusively used cross-sectional self-reported information on labor market outcomes. Short-term, cross-sectional measures of income, such as yearly earnings and hourly wages, contain idiosyncratic components that diminish the precision of the estimates (cf. Dahl et al., 2011). Register-based life-time earnings have much less measurement error than short-term measures. This accuracy increases the efficiency of the estimates, which is particularly important for relatively small samples, as in the twin pair differences. In our data, height is self-reported, but twin pair differences can be instrumented with measurements from another time point to alleviate the attenuation bias caused by the potential measurement error in self-reported height. 
We also examine explicitly the role of social skills in the height premium. This is important because Persico et al. (2004) argue that social skills explain the height premium. Furthermore, the literature has used only earnings as the outcome variable. We extend the literature by estimating separate effects on capital income that may provide additional insights about the underpinnings of the height premium. In addition, we evaluate the effect of height during different business cycle conditions, an effect that has been overlooked previously.

To the best of our knowledge, only one earlier study has used twin data to examine the height premium (Behrman and Rosenzweig, 2001). Their sample is restricted to female twins based on the Minnesota Twin Registry, and the estimates are obtained for cross-sectional, selfreported earnings. Using twin pair differences, Behrman and Rosenzweig (2001) find evidence for the existence of the height premium but no evidence for a wage penalty associated with obesity. ${ }^{8}$ Complementing the findings in Behrman and Rosenzweig (2001), we explore both male and female same-sex twins and thereby examine the possibility that outward attributes are treated differently in the labor market for men and women.

The remainder of the paper is structured as follows. Section 2 introduces the data. Section 3 outlines our empirical specifications. Section 4 reports descriptive evidence and the baseline estimation results. Section 5 discusses several additional specifications for assessing the robustness of the baseline results. Section 6 concludes.

\section{Data}

The twin data used in this study are based on the Older Finnish Twin Cohort Study of the Department of Public Health at the University of Helsinki. The initial twin data gathered in 1974 contain almost all same-sex DZ (dizygotic) and MZ (monozygotic) twins in the Finnish population born before 1958 (see Kaprio et al., 1979; Kaprio and Koskenvuo, 2002; Hyytinen 
et al., 2013; Maczulskij, 2013). ${ }^{9}$ The identification of twins was initially based on the comprehensive population register. Later, blood markers were tested for a small subsample of initially identified twins to confirm the identification of DZs and MZs. Height and weight are self-reported in the survey waves conducted in 1975 , 1981 and $1990 .^{10}$ The twin sample also contains retrospective, self-reported information on weight differences between twins at the ages of 10, 20 and 30 years reported in 1990.

We link the twin sample to the FLEED (Finnish Longitudinal Employer-Employee Data) maintained by Statistics Finland using personal ID codes owned by every person residing in Finland. This matching is exact, and there are no misreported ID codes. We therefore avoid problems associated with errors in record linkages (e.g., Ridder and Moffitt, 2007). The FLEED sample is constructed from a number of different registers of individuals and firms maintained by Statistics Finland. We use FLEED to measure earnings and exact labor market status as an average of the annual values over the period $1990-2004 .^{11}$ In particular, FLEED contains information from Employment Statistics that records the number of employment months during the year originating from the state-run pension registers that cover all legal employment contracts. Earnings data originate from comprehensive tax registers. Earnings are not top coded. Because the data on earnings contain some outliers, we have truncated the observations outside the $1^{\text {st }}$ and $99^{\text {th }}$ percentiles. Hyytinen et al. (2013, p. 63) document that the life-time labor market outcomes of the linked twin data are representative of the Finnish population.

To prevent education and early pension choices from affecting our life-time outcome measures, we restrict the analyses to primary working age persons. Therefore, all empirical specifications are estimated for individuals born after 1944 but before 1958. Thus, the twins are aged 33-59 years over the measurement period 1990-2004 for the life-time labor market 
outcomes. At the time of the survey years 1975, 1981, and 1990, they are, respectively, 17-30, 24-36, and 33-45 years old.

There are several different measures for social skills in the psychological literature, and there is no consensus on what constitutes the best measure for them (see Lorr et al., 1991). In our empirical analysis, latent social skills are measured by a summary measure dating from 1981 containing five different self-reported personality traits (open/closed, number of different interests, talkative/quiet, difficulty expressing feelings, and spontaneous/reserved). The responses to each of these five separate items range from 1-5. These traits are related to the ease and possibility of persons to engage in social relationships and thereby develop their social skills or utilize previously accumulated non-cognitive skills. This simple summary measure is closely related to the first factor from the standard principal component analysis. Higher values of the measure indicate that the person has worse social skills. The twin data do not contain the "Big Five” factors of personality (Barrick et al., 1991), but our summary measure of social skills contains aspects that are closely related to openness and extraversion, which are components of the Big Five.

Our data have some limitations that are important to consider in the interpretation of the estimates. In particular, the twin data do not contain information on birth weight or birth order. ${ }^{12}$ Because there is no information on the measures of body composition, such as waist circumference and fat mass, we focus on the effects of height on life-time labor market outcomes. ${ }^{13}$ However, we report the results for BMI (Body Mass Index) and discuss them briefly because weight is an important outward characteristic, along with height. ${ }^{14}$ 


\section{Empirical specifications}

In the empirical analysis, we first estimate individual-level OLS regressions of the following form for all individuals:

wage $_{\mathrm{ij1990-2004}}=$ constant $+a$ Height $_{\mathrm{ij} 1975}+b$ BMI $_{\mathrm{ij1975}}+$ controls $_{\mathrm{ij}}+$ error $_{\mathrm{ij}}$

where $\mathrm{j}=1,2$ (twin index) and $\mathrm{i}=1 . . . \mathrm{n}$ (twin pair index). The error term of the individual-level OLS regressions, error ${ }_{i j}=f_{i}+u_{i j}$, consists of two different components. The fixed effect, $\mathrm{fe}_{\mathrm{i}}$, represents unobserved factors that vary between twin pairs but do not vary within twin pairs, and $\mathrm{u}_{\mathrm{ij}}$ represents idiosyncratic individual-level factors. The parameters of interest are the effect of height and weight, as measured by BMI, on life-time earnings. Both height and BMI were measured in 1975.

We estimate OLS specifications that control for observed ability differences related to accumulated human capital using register-based information on education and incorporate potential work experience measured with age effects. There is some disagreement in the literature over whether one should control for educational attainment (and experience) when estimating models for the effects of anthropometric variables such as height and BMI on labor market outcomes (Kortt and Leigh, 2010, p. 72-73). The key question here is whether height and BMI affect earnings via education or whether they are correlated due to confounding factors or reverse causality. In the first case, the inclusion of education as a covariate would bias the effects of height and BMI on earnings, so one should not include it in the model. For example, Persico et al. (2004, p. 1031) argue that controlling for education leads to an underestimate of the effect of height on labor market outcomes, to the extent that human capital investments are simultaneously determined with greater stature (cf. Vogl 2012). ${ }^{15}$ 
In the second case, it is possible to argue that there are unobserved factors, such as ability and family background, that could act as confounding factors causing correlations between human capital and anthropometric measures. Therefore, omitting education and experience from covariates would cause an omitted variable bias to the effect of height and BMI on earnings. To safeguard against such biases we add controls for the observed ability differences between individuals to the OLS specifications and also to subsequent twin difference models, although the role of unobserved factors is minimized by twin differencing in estimations. The earlier studies that have examined BMI effects have typically controlled for educational attainment and experience (cf. Kortt and Leigh, 2010, p. 72-73). Regarding overweight, Webbink et al. (2010) show that education has a causal effect on body size and that reverse causality is most likely not an important concern. Also, the results in Behrman and Rosenzweig (2001) and Cawley (2004) suggest that it is important to control for education when studying the effects of BMI. For all these reasons, we include education and age among the covariates in our models. However, we have estimated the models for earnings also without controlling for education attainment (see Section 5.1). Note that we do not include occupation among the explanatory variables, because occupation is very likely to be endogenous with respect to height and thereby an important channel for the height premium to arise (see Lindqvist 2012). ${ }^{16}$

The twin difference models are estimated as follows:

$$
\text { Dwage }_{\text {i1990-2004 }}=a \text { DHeight }_{i 1975}+b \text { DBMI }_{\mathrm{i} 1975}+\text { Dcontrols }_{\mathrm{i}}+\text { Du }_{\mathrm{i}}
$$

where Dwage ${ }_{\mathrm{i} 1990-2004}=$ wage $_{\mathrm{i} 1,1990-2004}-$ wage $_{\mathrm{i} 2,1990-2004}$ is the difference in wages between twins within the twin pair i, and all the right-hand side variables are defined analogously. Twin difference models are estimated for DZ and MZ twins both pooled and separately. All 
factors common to both twins in a given twin pair included in $\mathrm{fe}_{\mathrm{i}}$ are differenced out. The MZ estimates remove the influence of both otherwise unobserved genetic traits and shared family background. The key assumption is that the twins have to have lived together in order to remove the family environment and the shared interactions of genes and family through this approach. Reassuringly, the fraction of twins who have not lived together prior to age 11 is very low ( 5\%) in these data (Kaprio et al., 1984). ${ }^{17}$

Structurally identical models are additionally estimated using employment as the outcome variable. All the specifications are estimated separately for women and men because the previous literature has shown that the height premium is larger for men and the obesity wage penalty is typically much larger for women. The additional reasons for separate specifications by gender are occupational sorting and the fact that women are, on average, shorter than men.

Height and weight were measured in 1975, and the life-time labor market outcomes were measured over the period 1990-2004. Due to this timing difference in the variables of interest, we are not worried about a reverse correlation between height and labor market outcomes. However, self-reported height and weight contain potential measurement error that attenuates the effects of height and BMI. ${ }^{18}$ The measurement error in the right-hand side variables would therefore result in conservative estimates for the effects of height and weight on subsequent labor market outcomes. For this reason, in the preferred specifications, we use Dheight $_{\text {i1981 }}$ and $\mathrm{DBMI}_{\mathrm{i} 1981}$ as instruments for Dheight ${ }_{\mathrm{i} 1975}$ and $\mathrm{DBMI}_{\mathrm{i} 1975}$, respectively, to correct for the attenuation bias caused by random measurement error. Twin differences in self-reported height and weight are strongly correlated across survey years. The validity of instruments is based on the classical measurement error assumption of non-correlated measurement errors in different survey years. Without the implementation of an instrumental variable (IV) 
estimation strategy, the estimates for the height premium and wage penalty would be biased towards zero.

Unobserved ability components related to both genetic and shared family factors are controlled for (differenced out) in the estimations that use twin differences. A substantial share of non-cognitive skills is also controlled for because they arise, for the most part, from parental inputs and peer group effects that are much more similar for both MZ and DZ twins than for randomly selected individuals for whom the effects of height are usually estimated using cross-sectional data. MZ twins share all genes, and their experiences related to the family environment and family resources are the same, assuming that they have lived together, as noted above. To the extent that a person's cognitive ability is determined by these factors, using twin pair differences for MZs constitutes a particularly strong control for unobserved ability differences between persons. Therefore, twin data are very useful to disentangle different explanations for the effect of height on earnings and employment prospects (Table 1).

Table 1 here

Silventoinen et al. (2004) show using twin data that the overwhelming majority (72-79\%) of the height variation between individuals is accounted for by additive genetic factors for both US and Finnish men and women. Shared family factors account for $11-19 \%$ of the variation, leaving 9-13\% for unshared environmental factors. Such factors include, for example, differences in fetal conditions or childhood disease experiences, which may differ even between MZ twins. However, there are also several other sources for differences in the development of MZ embryos that are documented in the medical literature, which can lead to discordant MZ twins who are dissimilar for certain characteristics such as height (Czyz et al., 2012; Van Dongen et al., 2012, p. 3). These sources constitute the height variation between 
twins that is not caused by measurement error and can be used to identify the effects of stature for twins. Whether this height variation is uncorrelated with unobserved differences in cognitive or non-cognitive skills between twins is an open issue of which very little is known. But we argue below in Section 5.4, based on our results, that MZ twin differences eliminate most of the effects of unobserved factors related to genetics or shared family environment that also correlate with height. The within twin-pair differences in unobserved factors seem to be much less important.

Individual-level OLS specifications are not able to discriminate between different explanations (Table 1, Column 1). DZ twins share only half of their genes but have similar family environment factors, as do MZ twins, implying that a comparison of DZ twins to cross-sectional individual-level OLS results identifies the contribution of the shared family environment component in the height premium and some of the genetic effects. Furthermore, a comparison of DZ and MZ estimates for the effect of height on labor market outcomes identifies the genetic component of unobserved ability differences.

In the twin data setting, the social skills explanation predicts that twin pair differences between DZs should largely remove the effect of height on earnings and employment prospects (Table 1, Column 2), assuming that social skills arise from family background and peer group effects that are mostly similar, even among DZ twins. In contrast, if the height premium is based on cognitive ability, twin pair differences for DZs should diminish it considerably, and twin pair differences for MZs should almost completely remove the effect of height on labor market outcomes. Furthermore, if discrimination is largely non-existent in capital income, it is possible to use additional information on capital income to obtain some suggestive evidence for the existence of discrimination against short persons (Table 1, Panel B, Column 3). ${ }^{19}$ 


\section{Results}

\subsection{Descriptive evidence}

Before the presentation of the estimation results, it is useful to note some essential features of the data. Table 2 reports the descriptive evidence for differences within twin pairs in the variables of interest. Differences in height, BMI and labor market outcomes are all notably smaller for MZs. Relatively small differences in variables between twin pairs may explain some of the variation in the estimates, especially for MZs. However, these differences do not reflect only measurement error, because self-reported height and weight have been validated for a subsample (see Korkeila et al., 1998). Furthermore, the range of height differences between twins is non-negligible, up to $10 \mathrm{~cm}$ even for MZ twins. The unconditional correlation between height and earnings is positive in all cases except for MZ men. ${ }^{20}$ We also find that differences in BMI increase over the period 1975-1990 because twins are ageing.

Table 2 here

\subsection{Baseline estimates}

To begin the analysis of twin differences, we first document that the estimated height premium is comparable to other studies when our twin data are used as standard crosssectional data. The individual-level OLS specifications reveal a positive height premium for both men and women (Table 3, Panels A-B, Columns 1). The quantitative magnitude of the wage effect $^{21}$ of height is $3.3 \%$ per $1 \mathrm{~cm}$ for men and $1.4 \%$ per $1 \mathrm{~cm}$ for women. The wage effect of BMI is $-3.9 \%$ per 1 unit in BMI for women, but for men it is not significant. Thus, the height premium controlling for observed human capital is considerably larger for men, but the wage penalty associated with obesity is larger for women. This pattern is consistent with 
the earlier studies that used various cross-sections of individuals. ${ }^{22}$ It is interesting that the height premium in our data is economically significant even though there is substantial wage compression in the Finnish labor market. The estimated height premium is in the upper range of the values obtained in previous studies. The literature has estimated that an additional inch of height is associated with a 0.025-5.5 percent increase in wages, according to Persico et al. (2004, p. 1020-1021). Our outcome is life-time earnings, not annual earnings, and therefore, the magnitude of our estimates is not completely comparable to those reported in the earlier studies.

Table 3 here

The specifications that use twin pair differences reveal that for both men and women, BMI is no longer statistically significant (Columns 3). For men, the positive height premium remains intact for DZs compared to the cross-sectional OLS results (Panel A, Column 4). This comparison shows that the family effects are not important determinants of the height premium. The result is consistent with Persico et al. (2004, p. 1030), who report that the height premium does not diminish much when controlling for family resources. However, the height premium disappears for male MZs (Column 5). This finding demonstrates that unobserved differences in ability (i.e. genetic traits) and such shared family effects that are more similar to MZ twins than DZ twins are the primary explanation for the height premium for men. However, for women, the height premium prevails for MZs at the $10 \%$ significance level. This result suggests a possible role for discrimination against short persons as an explanation for the height premium for women. We discuss possible explanations for the female height premium more in Section 5.4, including the possible role of within twin-pair differences in unobserved factors. 
Because both height and weight are self-reported, the estimates in Columns 3-5 may suffer from an attenuation bias. For this reason, in the preferred specifications, we use the IV strategy described earlier. The first stage of the IV approach works well. The F-test statistics are well above 10 when twin pair differences in height and BMI in 1975 are explained with the differences measured in 1981 (not reported).

For both men and women, the IV approach produces a larger point estimate, consistent with the estimates in Column 5 being downwardly biased because of the measurement error in selfreported height and weight. The IV estimates differ strikingly by gender. For men, height remains insignificant in the IV models (Panel A, Column 6). For women, the IV estimate for height is statistically significant. For women, the average wage effect of height in Column 6 is $\sim 19 \%$ using the average twin pair differences in height for MZs in Table $2 .^{23}$

The baseline specifications that use average employment months per year over the period 1990-2004 as a measure of labor market attachment are reported in Table 4. For men, the results in Panel A are very similar to those from the earlier wage models. The estimates in Panel B for women reveal that the employment effects of both height and BMI are much smaller than for men. One explanation for this pattern is occupational sorting; i.e., obese and/or short women are more often employed in low-wage occupations. This sorting creates larger effects in earnings than in employment.

Table 4 here

It is also useful to evaluate the quantitative magnitude of these estimates. For men, the employment effect of height is 0.05 months ( 1.5 days) per year for each $\mathrm{cm}$ using the estimate in Column 1 of Table 4. The effect of BMI is not significant for men. The estimates for women are lower and not significant. Thus, the employment effects are generally 
quantitatively small, which clearly implies that the earnings effects in Table 3 are being driven by the height premium in hourly or monthly wages rather than in labor market attachment. A striking pattern of these results is that, for women, height is also not significant in the employment models for MZs in Columns 4-5, in contrast to the wage models.

\section{Robustness and extensions}

To evaluate the sensitivity of the baseline estimates, we have estimated several alternative specifications. These models exploit the most important advantages of our linked data, which provide additional insights into the effects of height and weight on life-time labor market outcomes. We discuss these results briefly and present only the most interesting of them in subsequent tables.

\subsection{Exclusion of education}

We estimated all our models for earnings also without controlling for education (Appendix, Table A1). Our conclusions regarding the height effects in the preferred twin difference models remain intact. Even the quantitative magnitude of the coefficients is stable. Thus, controlling for observed ability differences clearly does not drive our results. ${ }^{24}$

The OLS estimates for both height and BMI from the models that omit education and age are much higher. Controlling for observed ability between individuals turns the BMI effect insignificant for men. A possible explanation for the substantial explanatory power of the observed ability differences in Table 3 is that education correlates with BMI, e.g. through time preference. Obese individuals may discount future outcomes more heavily (Smith et al., 2005; Schlam et al., 2012), and consequently, they acquire less education. However, the diminishing height effect is more difficult to explain with such omitted third factors because a 
person's height is not his or her own decision variable, but it could reflect genetic and family environment factors that affect both height and education. ${ }^{25}$

\subsection{Role of social skills}

Persico et al. (2004) argue that social skills constitute the primary explanation for the existence of the height premium. To study this argument, we have added a measure for social skills to the set of explanatory variables. ${ }^{26}$ Persico et al. (2004) used panel data on height and estimated a range of wage regressions with both adult height and teen height. They found that teen height matters for the height premium. Persico et al. (2004) interpreted this finding as evidence that non-cognitive skills (i.e. social skills) drive the height premium. Furthermore, they used high-school social activities for white men to measure social skills directly. Following Persico et al. (2004), we take advantage of a direct summary measure for social skills measured in 1981, which precedes the measurement of the labor market outcomes by a decade.

Unconditional correlations of the variables reveal that taller women have better social skills (Table 5). However, for Finnish men, social skills and height are only weakly related, which is in contrast with the results in Persico et al. (2004). We also observe that both obese men and obese women have poorer social skills. This relationship is stronger for women.

Table 5 here

The individual-level OLS models show that women with poor social skills have lower wages than women with strong social skills, even after controlling for the effects of accumulated human capital (Table 6, Panel B, Column 1). However, in contrast to the results in Persico et al. (2004), for Finnish men, there are no effects of social skills on life-time earnings (Table 6, 
Panel A, Column 1). One explanation for this observation is occupational sorting, i.e. men work in jobs where social skills are not required or rewarded. These apparent differences between genders are interesting because Persico et al. (2004) consider the contribution of social skills to the height premium only among white men.

Table 6 here

The specifications that use twin pair differences based on the IV strategy reveal that social skills are not significant in any of the models using life-time earnings as the outcome variable. Furthermore, the inclusion of social skills does not change the effect of height on earnings in the preferred specifications using the IV approach (Table 6, Column 5). In the specifications for employment, there is no role for social skills, not even in the individual-level OLS models for women (not reported). Based on these results, we conclude that social skills are not the comprehensive explanation for the existence of a height premium, as argued by Persico et al. (2004). A caveat is that our summary measure for social skills may contain measurement errors.

\subsection{Adding health to the covariates}

Lundborg et al. (2013) argue that the height premium in earnings can largely be explained by the positive association between height and physical capacity. Our twin data do not contain direct information on a person's physical capacity. However, we have comprehensive information on various diseases that were self-reported by the twins 15 years before our labor market outcomes in 1975. These diseases include, among others, emphysema, chronic obstructive pulmonary disease, high blood pressure, angina pectoris, peptic ulcer, diabetes, and gout. We use this information to evaluate the role of health as a proxy for physical capacity in the determination of the height premium in our twin sample. In the empirical 
specifications, we use the total number of different diseases that were self-reported in 1975. Because of the timing difference in the measurement of diseases and the labor market outcomes, reverse correlation is unlikely.

We first run regressions in which we explain the total number of different diseases in 1975 by height in 1975 while controlling for BMI in 1975. These results show that height is generally not even marginally statistically significantly associated with the number of diseases (not reported). Persico et al. (2004, p. 1037) report a similar finding. We have also estimated separate models for MZs. Only for female MZ twins is there some evidence that taller persons have fewer diseases. BMI is strongly positively associated with the number of diseases in all specifications, even for MZs.

Next, we add our health measure to the covariates for the specifications for earnings and employment months (not reported). These results show that the total number of diseases in 1975 is strongly and negatively associated with both of our labor market outcomes over the period 1990-2004. But the effect of height on earnings and average employment months remains intact. Even the quantitative magnitude of the height premium is essentially unchanged. Also, Persico et al. (2004, p. 1035) show that the addition of health covariates does not significantly reduce the estimated height premium. ${ }^{27}$ These results lead to the conclusion that height is not simply a proxy for good health. ${ }^{28}$

To sum up, health is not an important determinant of the height premium, but it has an independent effect on earnings and employment. Note that we also control for educational attainment; Lundborg (2013) shows that education has a causal effect on health. Our health measure captures chronic diseases in adulthood, in contrast to the childhood disease environment or health inputs in the model presented in Vogl (2012), where they act as a common input, creating a positive correlation between health and height as well as height and 
cognitive ability. This probably explains the lack of correlation between health and height in our twin data.

\subsection{Effects on capital income}

Using information on the different components of income, we estimate the height and weight effects for capital income. ${ }^{29}$ This analysis is an interesting extension of the existing literature because, usually, only annual earnings are used as the outcome variable. Bequests that generate unobserved differences in capital income do not cause problems in our analysis because we use data on twins, and bequests are divided equally by default among all children in Finland. Also, a long-term measure of capital income is particularly useful because capital income fluctuates substantially from year to year. To obtain a consistent time-series for capital income, these specifications are estimated for the years 1993-2004, covering the period after Finland adopted a dual income taxation system.

For both men and women, the individual-level OLS models reveal that height has a positive effect on capital income but that BMI is not significant (Table 7, Panels A-B). The models that use twin pair differences show that in the pooled sample of DZs and MZs there is a positive height premium for women but not for men. In the preferred specifications that use twin pair differences for MZs only with or without the IV approach, all the effects are insignificant for both men and women (Table 7, Panels A-B, Column 4).

Table 7 here

The tentative conclusion from these estimates is that discrimination against short persons may be part of the explanation of the height-wage premium for women because there is a height premium in wages in Table 3 (Panel B), but not when capital income is the outcome variable. 
This argument is based on the assumption that discrimination is less prevalent for the

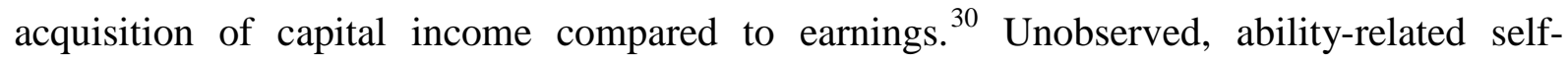
selection may create a cross-sectional correlation for height with earnings and capital income. The disappearance of this correlation in twin-pair differences for capital income but not for earnings gives support for our discrimination-based interpretation for women.

An alternative explanation could be within twin-pair differences in unobserved ability or noncognitive skills that correlate with height. Such effects cannot be ruled out due to possibly different nutritional conditions in utero that affect MZ twins differently, causing differences in birth weight, which has been shown to correlate with IQ (see Black et al., 2005 for evidence of such differences between twins). These early height differences may later in childhood and adolescence give rise to differences also in non-cognitive skills and selfconfidence via differing experiences in interactions with other people. But we can rule out this as a plausible explanation for the remaining height premium for MZ females in our data. Firstly, within-twin differences in ability imply that the height effect based on twin-pair differences is upward biased due to ability bias and therefore twin-difference estimates constitute an upper bound for the true estimate of height on earnings (Bound and Solon, 2004; Krashinsky, 2004, p. 789). Since our estimate for the height premium is insignificantly different from zero for MZ men, the within-twin differences in unobserved ability or their correlation with height must be small or non-existent. Secondly, unobserved skill-based explanations should apply similarly to both sexes and to capital income in addition to earnings. We are not aware of any evidence for gender specificity in the mechanisms creating unobserved cognitive or non-cognitive skill-based wage effects or their correlations with height. Therefore, we consider within-twin differences in unobserved factors to be an unlikely explanation for the female height premium, if such an effect does not manifest itself in the male height premium. This interpretation gains additional support from the fact that the female height effect is insignificant in capital income for MZ females, so that no unobserved 
within-twin differences seem to be present in capital income. This leaves discrimination to be the most likely explanation for the female height effect. Thirdly, Silventoinen et al. (2000, p. 483-484) discuss using the same Finnish twin data about the variation in fetal conditions between twins related to the twin transfusion syndrome, which is prevalent among MZ twins but not among DZ twins. They argue that the similarity for MZ and DZ twins in mean body height in educational groups does not support the importance of fetal conditions particular to twins in determining adult height. Therefore, within-twin differences in height-related ability seem to be unimportant, at least for this reason.

\subsection{Business cycle variation}

We have estimated the effects of height on labor market outcomes during different business cycle conditions (Appendix, Table A2). These results are particularly important because previous research almost exclusively uses cross-sectional data on earnings for a single year. Our data period, 1990-2004, contains a lot of variation in the income measures because it includes the severe depression of the early 1990s in Finland, which represents an exogenous shock caused by the collapse of Soviet trade (see Gorodnichenko et al., 2012). Real GDP fell by 14 percent over the period 1990-1994, and the unemployment rate increased to almost 17 percent from an average of approximately 5 percent during the 1980s. The depression also caused an abundance of variation in life-time labor market outcomes, which is useful in identifying the associated effects, especially for twin pairs.

We find that, for both men and women, the height premium in earnings is somewhat larger during the bottom of the depression (1993) compared to the peak of the economic upswing (1990). Using the estimates for these two years only, the pattern is much clearer for men. For men, the preferred point estimate for the IV specification in 1993 is 0.1879 , with a $95 \%$ confidence interval from 0.0247 to 0.3512 (Table A2, Panel B, Column 4). In contrast, the 
estimate for 1990 is not statistically significantly different from zero (Table A2, Panel A, Column 4). ${ }^{31}$ For men, the effects of height and BMI on employment months are also more pronounced during the depression (not reported). The results for both earnings and employment suggest that height may be a stronger signal for employers when the labor markets are tight. The finding that the height premium is not constant over the business cycle fluctuations provides one previously overlooked reason for the differences in the estimates of the height premium across earlier studies.

\subsection{Testing alternative IV strategies}

We have used retrospective information on weight differences between twins at the age of 20 reported in 1990 as an alternative instrument for BMI in 1975 (not reported). ${ }^{32}$ Again, the first stage of this IV approach works well. The F-test statistics are well above 10, the threshold proposed by Staiger and Stock (1997) for a weak instrument. These results show that BMI remains statistically insignificant for both men and women (not reported). Therefore, we conclude that there is no evidence for an obesity-related wage penalty.

One useful feature of our data is that they contain three different independent measurement points for both height and BMI. These measurements facilitate an alternative approach to account for the measurement error in self-reported information to test the robustness of our IV approach in the baseline specifications (not reported). We use the average of height and BMI over the three measurement points $(1975,1981$ and 1990) as an explanatory variable to reduce the effect of classical measurement error. The estimation results are similar to those in Tables 3-4. Notably, the results for MZs remain the same as in the previous models. 


\subsection{Accounting for age differences and using different measures for height}

Our explanatory variables for height and weight were measured in 1975. But the twin pairs were of different ages in 1975. This difference may cause some problems for the interpretation of the estimates. By estimating models with age groups in 1975 interacted with twin pair height differences, we can account for the fact that twin pairs had different ages in 1975 (not reported). The estimates based on both individual-level OLS and twin pair differences show that the effect of height is positive and statistically significant only for the youngest age groups even in the models for MZs. This pattern prevails for women but not for men.

We have also used information from the different measurement points for height and BMI, estimating separate specifications for 1981 and 1990 (not reported). The estimates of height and BMI measured in 1981 and 1990 are lower than the ones that use the measures from 1975, especially for men.

Both the specifications based on age groups in 1975 interacted with twin pair height differences, and the specifications estimated separately using weight and height in 1981 and 1990 are consistent with the argument that height differences at young ages are especially important for life-time labor market outcomes. Persico et al. (2004) raise this exact point. However, our results using a direct measure for social skills are not consistent with their specific explanation that this finding reflects the importance of non-cognitive skills. Alternatively, the measurement error in twin pair differences affects the estimation results arguably less for the young if the noise-to-signal ratio is smaller for them. 


\section{Conclusions}

In this paper, we examined the effect of height on life-time labor market outcomes using Finnish same-sex twin data to account for the unobserved biases in the earlier studies. The employment effects of height are quantitatively small, even in cross-sectional OLS specifications. Therefore, the earnings effect of height is driven by the height premium in hourly or monthly wages rather than in labor market attachment.

Accounting for unobserved ability and family effects using twin pair differences for genetically identical twins, we find no evidence for the effect of height on employment. This pattern prevails for both men and women. The observation supports the conclusions in Case and Paxton (2008) about the importance of cognitive ability in explaining the effect of height on labor market outcomes.

But the role of cognitive ability is more complex when using life-time earnings over the 15 year period as the outcome variable. The preferred estimates of twin pair differences with IV for genetically identical twins reveal a significant height premium for women but not for men. This finding implies that unobserved cognitive ability explains the effect of height on lifetime earnings for men but not for women. Since differences in cognitive ability do not fully account for the female height premium in life-time earnings, we use information on different sources of income to provide some additional light on the likely explanation. In particular, the disappearance of height premium for MZ female twins when using capital income as the outcome variable suggests that discrimination against short persons may play some role in explaining the height premium for women.

The non-existence of the height-wage premium for men implies an absence of significant upward bias from within-twin differences in ability, so that it is not an important factor in 
explaining the height premium. The cross-sectional height premium is explained by the shared genetic and environmental factors that are similar to MZ twins, but vary across random individuals. We argue that within-twin differences in ability do not explain the female height premium either, because it begs the question as to why it would affect women but not men, and ability bias should show up in the capital income estimates also if it is important.

We explicitly considered the potential contribution of social skills as the determinant of the height premium, following Persico et al. (2004). The results reveal that women with poor social skills have lower wages, based on individual-level OLS. However, this pattern does not prevail for men, and social skills do not play any role in twin pair difference estimates. Also, social skills do not account for the differences in employment in any of the models, not even the models based on individual-level OLS for women. Furthermore, both the estimates for life-time earnings and employment show that twin differences for DZs, which control for the family environment that constitutes the base for social contacts, are unable to remove the positive effect of height on life-time labor market outcomes. All these results point to the conclusion that social skills do not constitute a comprehensive explanation for the existence of the height premium, at least not in our twin sample.

Height may be just a marker of good health. However, we do not obtain evidence for the explanation that health is an important determinant of the height premium by using information on the prevalence of various diseases measured 15 years before our labor market outcomes. Health is an important determinant of life-time labor market outcomes, and persons with worse health obtain considerably lower wages later in life. But the effect of height on the labor market outcomes remains intact after adding information on diseases to the covariates.

We also find that the height premium is not constant over business cycle fluctuations; it seems to be somewhat larger during a depression, especially for men. This countercyclical nature of 
the height premium has not been documented elsewhere. Thus, height may be a more valuable characteristic when the labor markets are tight. While this new finding is interesting per se, it is not possible to use the result to settle the explanation for the height premium. Because our data contain only one severe depression, this pattern has to be studied also in other contexts.

All the empirical specifications that we estimated included BMI among the explanatory variables. In the preferred specifications, we find no evidence for a wage penalty from obesity. ${ }^{33}$ This finding applies to both men and women, and it is additionally robust to the use of an alternative instrument for BMI. Thus, we confirm the results in Behrman and Rosenzweig (2001) for men and women, using life-time labor market outcomes with different instrument variables strategies. This result is particularly important because the obesityrelated wage penalty is widely reported in the literature using non-twin data. 


\section{References}

Barrick, M. R., Mount, M. K., 1991. The big five personality dimensions and job performance: A meta-analysis. Personnel Psychology 44 (1), 1-26.

Behrman, J.R., Rosenzweig, M.R., 2001. The returns to increasing body weight. PIER Working Paper 01-052. Penn Institute for Economic Research.

Behrman, J.R., Rosenzweig, M.R., 2004. Returns to birthweight. The Review of Economics and Statistics 86 (2), 586-601.

Berggren, N., Jordahl, H., Poutvaara, P., 2010. The looks of a winner: Beauty and electoral success. Journal of Public Economics 94 (1-2), 8-15.

Björklund, A., Jäntti, M., 2012. How important is family background for labour-economic outcomes? Labour Economics 19 (4), 465-474.

Black, S.E., Devereux, P.J., Salvanes, K.G., 2005. From the cradle to the labor market? The effect of birth weight on adult outcomes. Quarterly Journal of Economics 122 (1), 409-439.

Bound, J., Solon, G., 1999. Double trouble: On the value of twins-based estimation of the return to schooling. Economics of Education Review 18 (2), 169-182.

Burkhauser, R.V., Cawley, J., 2008. Beyond BMI: The value of more accurate measures of fatness and obesity in social science research. Journal of Health Economics 27 (2), 519-529. 
Böckerman, P., Johansson, E., Kiiskinen, U., Heliövaara, M., 2010. The relationship between physical work and the height premium: Finnish evidence. Economics and Human Biology 8 (3), 414-420.

Case, A., Fertig, A., Paxson, C., 2005. The lasting impact of childhood health and circumstance. Journal of Health Economics 24 (2), 365-389.

Case, A., Paxson, C., 2008. Stature and status: Height, ability, and labor market outcomes. Journal of Political Economy 116 (3), 499-532.

Cawley, J., 2004. The impact of obesity on wages. Journal of Human Resources 39 (2), 451474.

Cinnirella, F., Winter, J., 2009. Size matters! Body height and labor market discrimination: A cross-European analysis. CESifo Working Paper No. 2733.

Czyz, W., Morahan, J.M., Ebers, G.C., Ramagopalan, S.V., 2012. Genetic, environmental and stochastic factors in monozygotic twin discordance with a focus on epigenetic differences. BMC Medicine, 10:93.

Dahl, M., DeLeire, T., Schwabish, J.A., 2011. Estimates of year-to-year volatility in earnings and in household incomes from administrative, survey, and matched data. Journal of Human Resources 21 (4), 750-774.

Gorodnichenko, Y., Mendoza, E.G., Tesar, L.L., 2012. The Finnish Great Depression: From Russia with love. The American Economic Review 102 (4), 1619-1643. 
Guéguen, N., 2012. Hair color and wages: Waitresses with blond hair have more fun. The Journal of Socio-Economics 41 (4), 370-372.

Hamermesh, D., Biddle, J., 1994. Beauty and the labor market. The American Economic Review 84 (5), 1174-1194.

Heckman, J.J., 1998. Detecting discrimination. Journal of Economic Perspectives 12 (2), 101116.

Hübler, O., 2009. The nonlinear link between height and wages in Germany, 1985-2004. Economics and Human Biology 7 (2), 191-199.

Hyytinen, A., Ilmakunnas, P., Toivanen, O., 2013. The return-to-entrepreneurship puzzle. Labour Economics 20 (1), 57-67.

Johansson, E., Böckerman, P., Kiiskinen, U. \& Heliövaara, M., 2009. Obesity and labour market success in Finland: The difference between having a high BMI and being fat. Economics and Human Biology 7 (1), 36-45.

Judge, T.A., Cable, D.M., 2004. The effect of physical height on workplace success and income: Preliminary test of a theoretical model. Journal of Applied Psychology 89 (3), 428441.

Kaprio, J., Artimo, M., Sarna, S., Rantasalo, I., 1979. The Finnish twin registry: Baseline characteristics. Section I: Materials methods, representativeness and results for variables special to twin studies. Department of Public Health, Publications, M(47). 
Kaprio, J., Koskenvuo, M., 2002. Genetic and environmental factors in complex diseases: The older Finnish Twin Cohort. Twin Research 5 (5), 358-365.

Kaprio, J., Koskenvuo, M., Langinvainio, H., 1984. Finnish twins reared apart. IV: Smoking and drinking habits. A preliminary analysis of the effect of heredity and environment. Acta Geneticae Medicae et Gemellologia 33 (3), 425-433.

Korkeila, M., Kaprio, J., Rissanen, A., Koskenvuo, M., Sörensen, T.I., 1998. Predictors of major weight gain in adult Finns: Stress, life satisfaction and personality traits. International Journal of Obesity and Related Metabolic Disorders 22 (10), 949-57.

Kortt, M., Leigh, A., 2010. Does size matter in Australia? Economic Record 86 (272), 71-83.

Krashinsky, H.A., 2004. Do marital status and computer usage really change the wage structure? Journal of Human Resources 39 (3), 774-791.

Lindqvist, E., 2012. Height and leadership. The Review of Economics and Statistics 94 (4), 1191-1196.

Lorr, M., Youniss, R. P., Stefic, E. C., 1991. An inventory of social skills. Journal of Personality Assessment 57 (3), 506-520.

Lundborg, P., 2013. The health returns to schooling - what can we learn from twins? Journal of Population Economics 26 (2), 673-701 
Lundborg, P., Nystedt, P., Rooth, D.-O., 2013. The height premium in earnings: The role of physical capacity and cognitive and non-cognitive skills. Journal of Human Resources, Forthcoming.

Maczulskij, T., 2013. Employment sector and pay gaps: Genetic and environmental influences. Labour Economics, Forthcoming.

McClearn, G.E., Johansson, B. Berg, S., Pedersen, N.L., Ahern, F., Petrill, S.A., Plomin, R., 2007. Substantial genetic influence on cognitive abilities in twins 80 or more years old. Science 276 (5318), 1560-1563.

McCrae, R.R., Costa Jr., P. T., Ostendorf, F., Angleitner, A., Hřebíčková, M., Avia, M. D., Sanz, J., Sánchez-Bernardos, M. L., Kusdil, M. E., Woodfield, R., Saunders, P, R., Smith, P. B., 2000. Nature over nurture: Temperament, personality, and life span development. Journal of Personality and Social Psychology 78 (1), 173-186.

Miller, P., Mulvey, C., Martin, N., 2005. Birth weight and schooling and earnings: Estimates from a sample of twins. Economics Letters 86 (3), 387-392.

Neal, D. A., Johnson, W. R., 1996. The role of premarket factors in black-white wage differences. Journal of Political Economy 104 (5), 896-895.

Persico, N., Postlewaite, A., Silverman, D., 2004. The effect of adolescent experience on labor market outcomes: The case of height. Journal of Political Economy 116 (3), 1019-1053.

Plomin, R., DeFries, J.C. 1998. The genetics of cognitive abilities and disabilities. Scientific American 278 (5), 62-69. 
Ridder, G., Moffitt, R., 2007. The econometrics of data combination. In Handbook of Econometrics, vol. 6B (eds J. J. Heckman and E. E. Leamer), pp. 5469-5547. Amsterdam: Elsevier.

Sargent, J. D., Blanchflower, D. G., 1994. Obesity and stature in adolescence and earnings in young adulthood - analysis of a British birth cohort. Archives of Pediatrics and Adolescent Medicine 148 (7), 681-687.

Sarlio-Lähteenkorva, S., Silventoinen, K., Lahelma, E., 2004. Relative weight and income at different levels of socioeconomic status. American Journal of Public Health 94 (3), 468-472.

Schlam, T.R., Wilson, N.L., Shoda, Y., Mischel, W., Ayduk, O., 2013. Preschoolers’ delay of gratification predicts their body mass 30 years later. The Journal of Pediatrics 162 (1), 91-93.

Silventoinen, K., Kaprio, J., Lahelma, E., 2000. Genetic and environmental contributions to the association between body height and educational attainment: A study of adult Finnish twins. Behavior Genetics 30 (6), 477-485.

Silventoinen, K., Kaprio, J., Lahelma, E., Viken, R.J., Rose, R.J., 2001. Sex differences in genetic and environmental factors contributing to body-height. Twin Research 4 (1), 25-29.

Silventoinen, K., Krueger, B., Bouchard Jr., T.J., Kaprio, J., McGue, M., 2004. Heritability of body height and educational attainment in an international context: Comparison of adult twins in Minnesota and Finland. American Journal of Human Biology 16 (5), 544-555. 
Smith, P. K., Bogin, B., Bishai, D., 2005. Are time preference and body mass index associated? Evidence from the National Longitudinal Survey of Youth. Economics and Human Biology 3 (2), 259-270.

Staiger, D., Stock, J. H., 1997. Instrumental variables regression with weak instruments. Econometrica 65 (3), 557-86.

Yusuf, S., Hawken, S., Ounpuu, S., Bautista, L., Franzosi, M.G., Commerford, P., Lang, C.C., Rumboldt, Z., Onen, C.L., Lisheng, L., Tanomsup, S., Wangai, P., Razak, F., Sharma, A.M., Anand, S.S., 2005. Obesity and the risk of myocardial infarction in 27000 participants from 52 countries: A case-control study. Lancet 366 (9497), 1640-1649.

Van Dongen, J., Slagboom, P.E., Draisma, H.H., Martin, N.G., Boomsma, D.I., 2012. The continuing value of twin studies in the omics era. Nature Reviews Genetics 13 (9), 640-653.

Vogl, T., 2012. Height, skills, and labor market outcomes in Mexico. NBER Working Paper No. 18318.

Wada, R., Tekin, E., 2010. Body composition and wages. Economics and Human Biology 8 (2), 242-254.

Webbink, D., Martin, N.G., Visscher, P.M., 2010. Does education reduce the probability of being overweight? Journal of Health Economics 29 (1), 29-39. 
Table 1. Using twin data to differentiate the explanations for the height premium.

\begin{tabular}{|l|l|l|l|}
\hline Panel A: Earnings & Individual-level OLS & Twin differences: DZ & Twin differences: MZ \\
\hline & & & \\
\hline Non-cognitive skills & + & 0 & 0 \\
\hline Cognitive skills & + & + (smaller $)$ & $\sim 0$ \\
\hline Discrimination & + & + & + \\
\hline Panel B: Capital income & Individual-level OLS & Twin differences: DZ & Twin differences: MZ \\
\hline & & & \\
\hline Non-cognitive skills & & 0 & 0 \\
\hline Cognitive skills & + & $+($ smaller $)$ & $\sim 0$ \\
\hline Discrimination & + & 0 & 0 \\
\hline
\end{tabular}

Notes: The table shows the expected impact of height on earnings and capital income according to different explanations of the height premium, conditional on all other explanatory factors being fully controlled. In Panel A, the outcome is earnings, and in Panel $\mathrm{B}$, the outcome is capital income. 
Table 2. Descriptive statistics.

Panel A: Men

\begin{tabular}{llll} 
& & \multicolumn{2}{c}{ Twin differences } \\
& DZ and MZ & DZ & MZ \\
Log wage & 1.9956 & 2.1584 & 1.6279 \\
Employment months & 3.0711 & 3.3341 & 2.4769 \\
& & & \\
Height (1975) & 3.7231 & 4.5974 & 1.7479 \\
Height (1981) & 3.8607 & 4.7425 & 1.9256 \\
Height (1990) & 3.7360 & 4.5560 & 2.0473 \\
& & & \\
BMI (1975) & 1.7344 & 1.9790 & 1.1817 \\
BMI (1981) & 2.0756 & 2.3813 & 1.4076 \\
BMI (1990) & 2.4730 & 2.7730 & 1.8542
\end{tabular}

Panel B: Women

\begin{tabular}{llll} 
& & \multicolumn{2}{c}{ Twin differences } \\
& DZ and MZ & DZ & MZ \\
Log wage & 2.0240 & 2.2168 & 1.6503 \\
Employment months & 3.2447 & 3.4735 & 2.8012 \\
& & & \\
Height (1975) & 3.3648 & 4.2624 & 1.6249 \\
Height (1981) & 3.4953 & 4.4202 & 1.7321 \\
Height (1990) & 3.4071 & 4.3595 & 1.7316 \\
& & & \\
BMI (1975) & 1.7433 & 2.0009 & 1.2441 \\
BMI (1981) & 2.1327 & 2.4447 & 1.5407 \\
BMI (1990) & 2.7554 & 3.1293 & 2.1022
\end{tabular}

Notes: Absolute differences between twin pairs are reported. Log wage is the average log annual wage over the period 1990-2004. Employment months are calculated as the average number of employment months per year over the period 1990-2004. Height (cm) and Body Mass Index (BMI) were measured in 1975, 1981 and 1990. Wage and employment months originate from FLEED. Height and weight are self-reported in the twin data. Descriptive statistics are calculated for individuals born after 1944 but before 1958 . 
Table 3. Wage regressions.

\begin{tabular}{|c|c|c|c|c|c|}
\hline \multicolumn{6}{|l|}{ Panel A: Men } \\
\hline Sample & $\mathrm{DZ}$ and $\mathrm{MZ}$ & $\mathrm{DZ}$ and $\mathrm{MZ}$ & $\mathrm{DZ}$ & $\mathrm{MZ}$ & $\mathrm{MZ}$ \\
\hline $\begin{array}{l}\text { Estimation } \\
\text { method }\end{array}$ & OLS & \multicolumn{3}{|c|}{ Twin differences } & $\begin{array}{l}\text { Twin differences } \\
\text { and IV }\end{array}$ \\
\hline $\begin{array}{l}\text { Dependent } \\
\text { variable }\end{array}$ & Log wage & Log wage & Log wage & Log wage & Log wage \\
\hline Height & $\begin{array}{l}0.0332 * * * \\
(0.0068)\end{array}$ & $\begin{array}{l}0.0319 * * \\
(0.0145)\end{array}$ & $\begin{array}{l}0.0364 * * \\
(0.0154)\end{array}$ & $\begin{array}{l}-0.0207 \\
(0.0419)\end{array}$ & $\begin{array}{l}0.1238 \\
(0.0843)\end{array}$ \\
\hline BMI & $\begin{array}{l}-0.0063 \\
(0.0175)\end{array}$ & $\begin{array}{l}0.0137 \\
(0.0334)\end{array}$ & $\begin{array}{l}0.0075 \\
(0.0374)\end{array}$ & $\begin{array}{l}0.0445 \\
(0.0707)\end{array}$ & $\begin{array}{l}-0.2202 \\
(0.1671)\end{array}$ \\
\hline Controls & Yes & Yes & Yes & Yes & Yes \\
\hline $\mathrm{N}$ & 4680 & 2340 & 1622 & 718 & 589 \\
\hline \multicolumn{6}{|c|}{ Panel B: Women } \\
\hline Sample & $\overline{D Z}$ and $\mathrm{MZ}$ & $\mathrm{DZ}$ and $\mathrm{MZ}$ & $\mathrm{DZ}$ & $\mathrm{MZ}$ & $\mathrm{MZ}$ \\
\hline $\begin{array}{l}\text { Estimation } \\
\text { method }\end{array}$ & OLS & \multicolumn{3}{|c|}{ Twin differences } & $\begin{array}{l}\text { Twin differences } \\
\text { and IV }\end{array}$ \\
\hline $\begin{array}{l}\text { Dependent } \\
\text { variable }\end{array}$ & Log wage & Log wage & Log wage & Log wage & Log wage \\
\hline Height & $\begin{array}{l}0.0141^{* *} \\
(0.0068)\end{array}$ & $\begin{array}{l}0.0411 * * * \\
(0.0159)\end{array}$ & $\begin{array}{l}0.0373 * * \\
(0.0170)\end{array}$ & $\begin{array}{l}0.0726 * \\
(0.0421)\end{array}$ & $\begin{array}{l}0.1155^{* *} \\
(0.0558)\end{array}$ \\
\hline BMI & $\begin{array}{l}-0.0386^{* *} \\
(0.0160)\end{array}$ & $\begin{array}{l}-0.0200 \\
(0.0313)\end{array}$ & $\begin{array}{l}-0.0227 \\
(0.0364)\end{array}$ & $\begin{array}{l}-0.0074 \\
(0.0572)\end{array}$ & $\begin{array}{l}-0.0517 \\
(0.1237)\end{array}$ \\
\hline $\begin{array}{l}\text { Controls } \\
\mathrm{N}\end{array}$ & $\begin{array}{l}\text { Yes } \\
5060\end{array}$ & $\begin{array}{l}\text { Yes } \\
2530\end{array}$ & $\begin{array}{l}\text { Yes } \\
1669\end{array}$ & $\begin{array}{l}\text { Yes } \\
861\end{array}$ & $\begin{array}{l}\text { Yes } \\
765\end{array}$ \\
\hline $\mathrm{N}$ & 5060 & 2530 & 1669 & 861 & 765 \\
\hline
\end{tabular}

Notes: Log wage is the average log annual wage over the period 1990-2004. Height and BMI were measured in 1975. In Column 1, education level (6 groups) and age, both squared and cubed, are included in the vector of explanatory variables. In Columns 2-5, the difference in the years of education between twin pairs is included in the right-hand side variables. In Column 5, height and BMI differences measured in 1981 are used as instruments for height and BMI differences in 1975. All specifications are estimated for individuals born after 1944 but before 1958. Robust standard errors are reported in parentheses: *statistically significant at the .10 level; **at the .05 level; ***at the .01 level. 
Table 4. Employment regressions.

\begin{tabular}{|c|c|c|c|c|c|}
\hline \multicolumn{6}{|l|}{ Panel A: Men } \\
\hline Sample & $\mathrm{DZ}$ and $\mathrm{MZ}$ & $\mathrm{DZ}$ and $\mathrm{MZ}$ & $\mathrm{DZ}$ & $\mathrm{MZ}$ & $\mathrm{MZ}$ \\
\hline $\begin{array}{l}\text { Estimation } \\
\text { method }\end{array}$ & OLS & & Twin differences & & $\begin{array}{l}\text { Twin differences } \\
\text { and IV }\end{array}$ \\
\hline $\begin{array}{l}\text { Dependent } \\
\text { variable }\end{array}$ & $\begin{array}{l}\text { Employment } \\
\text { months }\end{array}$ & $\begin{array}{l}\text { Employment } \\
\text { months }\end{array}$ & $\begin{array}{l}\text { Employment } \\
\text { months }\end{array}$ & $\begin{array}{l}\text { Employment } \\
\text { Months }\end{array}$ & $\begin{array}{l}\text { Employment } \\
\text { months }\end{array}$ \\
\hline Height & $\begin{array}{l}0.0462 * * * \\
(0.0096)\end{array}$ & $\begin{array}{l}0.0463 * * \\
(0.0210)\end{array}$ & $\begin{array}{l}0.0508 * * \\
(0.0221)\end{array}$ & $\begin{array}{l}-0.0034 \\
(0.0641)\end{array}$ & $\begin{array}{l}0.0837 \\
(0.1170)\end{array}$ \\
\hline BMI & $\begin{array}{l}-0.0309 \\
(0.0245)\end{array}$ & $\begin{array}{l}-0.0081 \\
(0.0473)\end{array}$ & $\begin{array}{l}-0.0144 \\
(0.0526)\end{array}$ & $\begin{array}{l}0.0202 \\
(0.1050)\end{array}$ & $\begin{array}{l}-0.1096 \\
(0.2506)\end{array}$ \\
\hline Controls & Yes & Yes & Yes & Yes & Yes \\
\hline $\mathrm{N}$ & 4680 & 2340 & 1622 & 718 & 589 \\
\hline \multicolumn{6}{|c|}{ Panel B: Women } \\
\hline Sample & $\mathrm{DZ}$ and $\mathrm{MZ}$ & $\mathrm{DZ}$ and $\mathrm{MZ}$ & $\mathrm{DZ}$ & $\mathrm{MZ}$ & $\mathrm{MZ}$ \\
\hline $\begin{array}{l}\text { Estimation } \\
\text { method }\end{array}$ & OLS & & Twin differences & & $\begin{array}{l}\text { Twin differences } \\
\text { and IV }\end{array}$ \\
\hline $\begin{array}{l}\text { Dependent } \\
\text { variable }\end{array}$ & $\begin{array}{l}\text { Employment } \\
\text { months }\end{array}$ & $\begin{array}{l}\text { Employment } \\
\text { months }\end{array}$ & $\begin{array}{l}\text { Employment } \\
\text { months }\end{array}$ & $\begin{array}{l}\text { Employment } \\
\text { Months }\end{array}$ & $\begin{array}{l}\text { Employment } \\
\text { months }\end{array}$ \\
\hline Height & $\begin{array}{l}0.0125 \\
(0.0099)\end{array}$ & $\begin{array}{l}0.0352 \\
(0.0231)\end{array}$ & $\begin{array}{l}0.0384 \\
(0.0245)\end{array}$ & $\begin{array}{l}0.0038 \\
(0.0675)\end{array}$ & $\begin{array}{l}0.0623 \\
(0.1020)\end{array}$ \\
\hline BMI & $\begin{array}{l}-0.0290 \\
(0.0231)\end{array}$ & $\begin{array}{l}-0.0074 \\
(0.0443)\end{array}$ & $\begin{array}{l}0.0107 \\
(0.0515)\end{array}$ & $\begin{array}{l}-0.0754 \\
(0.0823)\end{array}$ & $\begin{array}{l}-0.1864 \\
(0.1851)\end{array}$ \\
\hline Controls & Yes & Yes & Yes & Yes & Yes \\
\hline $\mathrm{N}$ & 5060 & 2530 & 1669 & 861 & 765 \\
\hline
\end{tabular}

Notes: Employment months are calculated as the average number of employment months per year over the period 1990-2004. Height and BMI were measured in 1975. In Column 1, education level (6 groups) and age, both squared and cubed, are included in the vector of explanatory variables. In Columns 2-5, the difference in the years of education between twin pairs is included in the right-hand side variables. In Column 5, height and BMI differences measured in 1981 are used as instruments for height and BMI differences in 1975. All specifications are estimated for individuals born after 1944 but before 1958. Robust standard errors are reported in parentheses: *statistically significant at the .10 level; **at the .05 level; ***at the .01 level. 
Table 5. Correlations between height, BMI and social skills.

\begin{tabular}{|c|c|c|c|}
\hline Panel A: Men & Height (1975) & BMI (1975) & Social skills (1981) \\
\hline Height (1975) & 1 & & \\
\hline BMI (1975) & $\begin{array}{l}-0.0411^{* * *} \\
(0.0000)\end{array}$ & 1 & \\
\hline Social skills (1981) & $\begin{array}{l}-0.0087^{* *} \\
(0.0277) \\
\end{array}$ & $\begin{array}{l}-0.0291^{* * *} \\
(0.0000)\end{array}$ & 1 \\
\hline Panel B: Women & Height (1975) & BMI (1975) & Social skills (1981) \\
\hline Height (1975) & 1 & & \\
\hline BMI (1975) & $\begin{array}{l}-0.0675^{* * *} \\
(0.0000)\end{array}$ & 1 & \\
\hline Social skills (1981) & $\begin{array}{l}-0.0296^{* * *} \\
(0.0000)\end{array}$ & $\begin{array}{l}-0.0636 * * * \\
(0.0000)\end{array}$ & 1 \\
\hline
\end{tabular}

Notes: Social skills are measured as explained in the text. Higher values indicate worse social skills. The correlations are calculated for individuals born after 1944 but before 1958. $\mathrm{p}$-values in parentheses. Statistical significance: ${ }^{* * *} \mathrm{p}<0.01,{ }^{* *} \mathrm{p}<0.05,{ }^{*} \mathrm{p}<0.1$. 
Table 6. Wage regressions with a measure for social skills.

\begin{tabular}{|c|c|c|c|c|c|}
\hline \multicolumn{6}{|l|}{ Panel A: Men } \\
\hline Sample & $\mathrm{DZ}$ and $\mathrm{MZ}$ & $\mathrm{DZ}$ and $\mathrm{MZ}$ & $\mathrm{DZ}$ & $\mathrm{MZ}$ & $\mathrm{MZ}$ \\
\hline $\begin{array}{l}\text { Estimation } \\
\text { method }\end{array}$ & OLS & \multicolumn{3}{|c|}{ Twin differences } & $\begin{array}{l}\text { Twin differences } \\
\text { and IV }\end{array}$ \\
\hline Height & $\begin{array}{l}0.0182 * * * \\
(0.0067)\end{array}$ & $\begin{array}{l}0.0312^{* *} \\
(0.0149)\end{array}$ & $\begin{array}{l}0.0308 * * \\
(0.0158)\end{array}$ & $\begin{array}{l}0.0294 \\
(0.0427)\end{array}$ & $\begin{array}{l}0.0688 \\
(0.0652)\end{array}$ \\
\hline BMI & $\begin{array}{l}-0.0139 \\
(0.0194)\end{array}$ & $\begin{array}{l}0.0070 \\
(0.0352)\end{array}$ & $\begin{array}{l}0.0077 \\
(0.0393)\end{array}$ & $\begin{array}{l}-0.0010 \\
(0.0760)\end{array}$ & $\begin{array}{l}-0.1830 \\
(0.1624)\end{array}$ \\
\hline Social skills & $\begin{array}{l}-0.0019 \\
(0.0094)\end{array}$ & $\begin{array}{l}0.0048 \\
(0.0139)\end{array}$ & $\begin{array}{l}0.0138 \\
(0.0162)\end{array}$ & $\begin{array}{l}-0.0272 \\
(0.0264)\end{array}$ & $\begin{array}{l}-0.0285 \\
(0.0267)\end{array}$ \\
\hline Controls & Yes & Yes & Yes & Yes & Yes \\
\hline $\mathrm{N}$ & 3680 & 1840 & 1270 & 570 & 566 \\
\hline \multicolumn{6}{|c|}{ Panel B: Women } \\
\hline Sample & $\overline{D Z}$ and $\mathrm{MZ}$ & $\mathrm{DZ}$ and $\mathrm{MZ}$ & $\mathrm{DZ}$ & $\mathrm{MZ}$ & $\mathrm{MZ}$ \\
\hline $\begin{array}{l}\text { Estimation } \\
\text { method }\end{array}$ & OLS & \multicolumn{3}{|c|}{ Twin differences } & $\begin{array}{l}\text { Twin differences } \\
\text { and IV }\end{array}$ \\
\hline Height & $\begin{array}{l}0.0175^{* *} \\
(0.0070)\end{array}$ & $\begin{array}{l}0.0376 * * \\
(0.0166)\end{array}$ & $\begin{array}{l}0.0347 * * \\
(0.0177)\end{array}$ & $\begin{array}{l}0.0625 \\
(0.0434)\end{array}$ & $\begin{array}{l}0.1216 * * \\
(0.0574)\end{array}$ \\
\hline BMI & $\begin{array}{l}-0.0239 \\
(0.0173)\end{array}$ & $\begin{array}{l}-0.0256 \\
(0.0327)\end{array}$ & $\begin{array}{l}-0.0219 \\
(0.0381)\end{array}$ & $\begin{array}{l}-0.0392 \\
(0.0599)\end{array}$ & $\begin{array}{l}-0.0810 \\
(0.1268)\end{array}$ \\
\hline Social skills & $\begin{array}{l}-0.0226 * * * \\
(0.0081)\end{array}$ & $\begin{array}{l}-0.0083 \\
(0.0121)\end{array}$ & $\begin{array}{l}-0.0117 \\
(0.0148)\end{array}$ & $\begin{array}{l}-0.0017 \\
(0.0197)\end{array}$ & $\begin{array}{l}-0.0019 \\
(0.0199)\end{array}$ \\
\hline Controls & Yes & Yes & Yes & Yes & Yes \\
\hline $\mathrm{N}$ & 4298 & 2149 & 1404 & 745 & 735 \\
\hline
\end{tabular}

Notes: The dependent variable is the average log annual wage over the period 1990-2004. See also notes to Table 3. Social skills are measured as explained in the text. Higher values indicate worse social skills. Robust standard errors are reported in parentheses: *statistically significant at the .10 level; **at the .05 level; ***at the .01 level. 
Table 7. Explaining capital income.

\begin{tabular}{|c|c|c|c|c|}
\hline \multicolumn{5}{|l|}{ Panel A: Men } \\
\hline Sample & $\mathrm{DZ}$ and $\mathrm{MZ}$ & $\mathrm{DZ}$ and $\mathrm{MZ}$ & $\mathrm{MZ}$ & MZ \\
\hline $\begin{array}{l}\text { Estimation } \\
\text { method }\end{array}$ & OLS & \multicolumn{2}{|c|}{ Twin differences } & $\begin{array}{l}\text { Twin } \\
\text { differences } \\
\text { and IV }\end{array}$ \\
\hline Height & $\begin{array}{l}0.0334 * * * \\
(0.0064)\end{array}$ & $\begin{array}{l}0.0134 \\
(0.0135)\end{array}$ & $\begin{array}{l}0.0167 \\
(0.0374)\end{array}$ & $\begin{array}{l}0.0440 \\
(0.0628)\end{array}$ \\
\hline BMI & $\begin{array}{l}0.0206 \\
(0.0168)\end{array}$ & $\begin{array}{l}0.0071 \\
(0.0293)\end{array}$ & $\begin{array}{l}-0.0769 \\
(0.0747)\end{array}$ & $\begin{array}{l}0.0223 \\
(0.1758)\end{array}$ \\
\hline Controls & Yes & Yes & Yes & Yes \\
\hline $\mathrm{N}$ & 4614 & 2307 & 710 & 582 \\
\hline \multicolumn{5}{|c|}{ Panel B: Women } \\
\hline Sample & DZ and $\mathrm{MZ}$ & $\mathrm{DZ}$ and MZ & $\mathrm{MZ}$ & $\mathrm{MZ}$ \\
\hline $\begin{array}{l}\text { Estimation } \\
\text { method }\end{array}$ & OLS & \multicolumn{2}{|c|}{ Twin differences } & $\begin{array}{l}\text { Twin } \\
\text { differences } \\
\text { and IV }\end{array}$ \\
\hline Height & $\begin{array}{l}0.0099 * \\
(0.0057)\end{array}$ & $\begin{array}{l}0.0220^{*} \\
(0.0123)\end{array}$ & $\begin{array}{l}0.0309 \\
(0.0336)\end{array}$ & $\begin{array}{l}0.0605 \\
(0.0546)\end{array}$ \\
\hline BMI & $\begin{array}{l}-0.0137 \\
(0.0125)\end{array}$ & $\begin{array}{l}-0.0267 \\
(0.0236)\end{array}$ & $\begin{array}{l}-0.0347 \\
(0.0526)\end{array}$ & $\begin{array}{l}0.0865 \\
(0.1021)\end{array}$ \\
\hline Controls & Yes & Yes & Yes & Yes \\
\hline $\mathrm{N}$ & 5006 & 2503 & 853 & 759 \\
\hline
\end{tabular}

Notes: The dependent variable is the average of log annual capital income over the period 1993-2004. Height and BMI were measured in 1975. In Column 1, education level (6 groups) and age, both squared and cubed, are included in the vector of explanatory variables. In

Columns 2-4, the difference in the years of education between twin pairs is included in the right-hand side variables. In Column 4, height and BMI differences measured in 1981 are used as instruments for height and BMI differences in 1975. All specifications are estimated for individuals born after 1944 but before 1958. Robust standard errors are reported in parentheses: *statistically significant at the .10 level; **at the .05 level; ***at the .01 level. 


\section{Appendix}

Table A1. Wage regressions without controlling for education.

\begin{tabular}{|c|c|c|c|c|c|}
\hline \multicolumn{6}{|c|}{ Panel A: Men } \\
\hline Sample & $\mathrm{DZ}$ and $\mathrm{MZ}$ & $\mathrm{DZ}$ and $\mathrm{MZ}$ & $\mathrm{DZ}$ & $\mathrm{MZ}$ & MZ \\
\hline $\begin{array}{l}\text { Estimation } \\
\text { method }\end{array}$ & OLS & \multicolumn{3}{|c|}{ Twin differences } & $\begin{array}{l}\text { Twin } \\
\text { differences } \\
\text { and IV }\end{array}$ \\
\hline Height & $\begin{array}{l}0.0449 * * * \\
(0.0070)\end{array}$ & $\begin{array}{l}0.0352 * * \\
(0.0148)\end{array}$ & $\begin{array}{l}0.0397 * * \\
(0.0156)\end{array}$ & $\begin{array}{l}-0.0163 \\
(0.0432)\end{array}$ & $\begin{array}{l}0.1387 \\
(0.0882)\end{array}$ \\
\hline BMI & $\begin{array}{l}-0.0360^{* *} \\
(0.0160)\end{array}$ & $\begin{array}{l}-0.0074 \\
(0.0339)\end{array}$ & $\begin{array}{l}-0.0140 \\
(0.0378)\end{array}$ & $\begin{array}{l}0.0263 \\
(0.0734)\end{array}$ & $\begin{array}{l}-0.2737 \\
(0.1749)\end{array}$ \\
\hline Controls & No & No & No & No & No \\
\hline $\mathrm{N}$ & 4680 & 2340 & 1622 & 718 & 589 \\
\hline \multicolumn{6}{|c|}{ Panel B: Women } \\
\hline Sample & $\mathrm{DZ}$ and $\mathrm{MZ}$ & $\mathrm{DZ}$ and $\mathrm{MZ}$ & $\mathrm{DZ}$ & $\mathrm{MZ}$ & $\mathrm{MZ}$ \\
\hline $\begin{array}{l}\text { Estimation } \\
\text { method }\end{array}$ & OLS & \multicolumn{3}{|c|}{ Twin differences } & $\begin{array}{l}\text { Twin } \\
\text { differences } \\
\text { and IV }\end{array}$ \\
\hline Height & $\begin{array}{l}0.0219 * * * \\
(0.0070)\end{array}$ & $\begin{array}{l}0.0468 * * * \\
(0.0162)\end{array}$ & $\begin{array}{l}0.0434 * * \\
(0.0173)\end{array}$ & $\begin{array}{l}0.0778 * \\
(0.0420)\end{array}$ & $\begin{array}{l}0.1176^{* *} \\
(0.0559)\end{array}$ \\
\hline BMI & $\begin{array}{l}-0.0561 \text { *** } \\
(0.0160)\end{array}$ & $\begin{array}{l}-0.0220 \\
(0.0319)\end{array}$ & $\begin{array}{l}-0.0258 \\
(0.0372)\end{array}$ & $\begin{array}{l}-0.0067 \\
(0.0572)\end{array}$ & $\begin{array}{l}-0.0627 \\
(0.1258)\end{array}$ \\
\hline Controls & No & No & No & No & No \\
\hline $\mathrm{N}$ & 5060 & 2530 & 1669 & 861 & 765 \\
\hline
\end{tabular}

Notes: The dependent variable is the average log annual wage over the period 1990-2004. Height and BMI were measured in 1975. In Column 5, height and BMI differences measured in 1981 are used as instruments for height and BMI differences in 1975. All specifications are estimated for individuals born after 1944 but before 1958. Robust standard errors are reported in parentheses: *statistically significant at the .10 level; **at the .05 level; ***at the .01 level 
Table A2. Wage regressions for men in 1990 and 1993.

\begin{tabular}{|c|c|c|c|c|}
\hline \multicolumn{5}{|c|}{ Panel A: Men (1990) } \\
\hline Sample & $\mathrm{DZ}$ and $\mathrm{MZ}$ & $\mathrm{DZ}$ and $\mathrm{MZ}$ & $\mathrm{MZ}$ & $\mathrm{MZ}$ \\
\hline $\begin{array}{l}\text { Estimation } \\
\text { method }\end{array}$ & OLS & \multicolumn{2}{|c|}{ Twin differences } & $\begin{array}{l}\text { Twin } \\
\text { differences } \\
\text { and IV }\end{array}$ \\
\hline Height & $\begin{array}{l}0.0224^{* * *} \\
(0.0064)\end{array}$ & $\begin{array}{l}0.0199 \\
(0.0138)\end{array}$ & $\begin{array}{l}-0.0466 \\
(0.0445)\end{array}$ & $\begin{array}{l}0.0642 \\
(0.0737)\end{array}$ \\
\hline BMI & $\begin{array}{l}0.0027 \\
(0.0163)\end{array}$ & $\begin{array}{l}-0.0086 \\
(0.0299)\end{array}$ & $\begin{array}{l}0.0336 \\
(0.0679)\end{array}$ & $\begin{array}{l}0.1406 \\
(0.1661)\end{array}$ \\
\hline Controls & Yes & Yes & Yes & Yes \\
\hline $\mathrm{N}$ & 4680 & 2340 & 718 & 589 \\
\hline \multicolumn{5}{|c|}{ Panel B: Men (1993) } \\
\hline Sample & $\mathrm{DZ}$ and $\mathrm{MZ}$ & $\mathrm{DZ}$ and $\mathrm{MZ}$ & $\mathrm{MZ}$ & $\mathrm{MZ}$ \\
\hline $\begin{array}{l}\text { Estimation } \\
\text { method }\end{array}$ & OLS & \multicolumn{2}{|c|}{ Twin differences } & $\begin{array}{l}\text { Twin } \\
\text { differences } \\
\text { and IV }\end{array}$ \\
\hline Height & $\begin{array}{l}0.0286^{* * *} \\
(0.0081)\end{array}$ & $\begin{array}{l}0.0261 \\
(0.0164)\end{array}$ & $\begin{array}{l}0.0144 \\
(0.0542)\end{array}$ & $\begin{array}{l}0.1879 * * \\
(0.0831)\end{array}$ \\
\hline BMI & $\begin{array}{l}-0.0232 \\
(0.0205)\end{array}$ & $\begin{array}{l}0.0200 \\
(0.0367)\end{array}$ & $\begin{array}{l}0.1949 * * \\
(0.0847)\end{array}$ & $\begin{array}{l}0.1120 \\
(0.1963)\end{array}$ \\
\hline Controls & Yes & Yes & Yes & Yes \\
\hline $\mathrm{N}$ & 4614 & 2307 & 710 & 582 \\
\hline
\end{tabular}

Notes: The dependent variable is the log annual wage in 1990 (Panel A) or in 1993 (Panel B). Height and BMI were measured in 1975. In Column 1, education level (6 groups) and age, both squared and cubed, are included in the vector of explanatory variables. In Columns 2-4, the difference in the years of education between twin pairs is included in the right-hand side variables. In Column 4, height and BMI differences measured in 1981 are used as instruments for height and BMI differences in 1975. All specifications are estimated for individuals born after 1944 but before 1958. Robust standard errors are reported in parentheses: *statistically significant at the .10 level; **at the .05 level; ***at the .01 level. 
${ }^{1}$ In this literature, earnings are more commonly used than employment as a measure of labor market success. In this paper, the term 'height premium' refers to both earnings and employment outcomes.

${ }^{2}$ Persico et al. (2004) use the National Longitudinal Survey of Youth (NLSY) from 1979 and focus on white men. Their baseline specifications explain wages with height measured at the ages of 7, 11, 16 and 33. Persico et al. (2004, p. 1033) find that, among all recorded heights, only height at age 16 has an economically large and statistically significant effect on adult wages. Their additional specifications take advantage of information on participation in high school social activities.

${ }^{3}$ The study by Case and Paxson (2008) is partly based on the same data as the one by Persico et al. (2004) but Case and Paxson (2008) also use additional information on childhood cognitive ability.

${ }^{4}$ Lundborg et al. (2013) use data from the Swedish military enlistment register over the period 1984-1997 and income data for 2003. They estimate wage regressions for 2003 with height, cognitive and non-cognitive skills, and physical strength as explanatory variables.

${ }^{5}$ The one difference between using data on non-identical twins and siblings is that with nonidentical twins there is no need to control for age differences. Björklund and Jäntti (2012) stress the importance of the family environment on various labor market outcomes using Swedish sibling data.

${ }^{6}$ The twin correlation for general cognitive ability and verbal ability is in the range of 0.7-0.8 for identical twins and about half that amount for non-identical twins (see McClearn et al., 1997, p. 1562; Plomin and DeFries, 1998, p. 66). 
${ }^{7}$ There is a growing literature on the effects of early life experiences on subsequent labor market outcomes in economics (e.g., Case et al., 2005). Early life experiences may additionally shape personality (e.g., McCrae et al., 2000).

${ }^{8}$ Behrman and Rosenzweig (2001) report that each additional inch of height is associated with a 3.5-5.5 percent increase in wages for female identical twins.

${ }^{9}$ Dizygotic or 'fraternal' twins share, on average, $50 \%$ of their genes. There are some exceptions to the rule that MZ twins are genetically identical (Van Dongen et al., 2012, p. 11).

${ }^{10}$ Earlier studies have used the height information in the Finnish twin data (e.g., Silventoinen et al., 2000, 2001, 2004). However, none of these studies has examined the effect of height on labor market outcomes.

${ }^{11}$ We calculate the average earnings over the period 1990-2004 first by taking a logarithmic transformation of yearly earnings and then calculating the average. The idea is to normalize the earnings data and suppress the effect of outliers caused by the depression of the early 1990s and other transitional earnings effects.

${ }^{12}$ Behrman and Rosenzweig (2004) and Black et al. (2005) consider the importance of birth weight on subsequent labor market outcomes. Using a sample of Australian twins, Miller et al. (2005) show that birth weight has only a minor role in the determination of earnings. This result suggests that the omission of birth weight is not necessarily important in a twin setting.

${ }^{13}$ In the medical literature, BMI alone is not considered a valid measure of obesity or a sufficient predictor of obesity-related health outcomes (Yusuf et al., 2005). One reason is that BMI blurs the distinction between fat and fat-free mass, such as muscle and bone. Only some recent empirical studies have used body composition in economics to examine the labor 
market effects of obesity (see Burkhauser and Cawley, 2008, Johansson et al., 2009; Wada and Tekin, 2010).

${ }^{14}$ Body mass index is calculated as a person's weight in kilograms divided by height in meters squared.

${ }^{15}$ Decision variables among the right-hand side covariates would be 'bad controls' when estimating the effects on earnings. (See Neal and Johnson, 1996; Heckman, 1998; and Kortt and Leigh, 2010 for discussions of this issue.)

${ }^{16}$ Vogl (2012) reports that taller Mexican workers sort into occupations that require greater intelligence and lower physical strength.

17 Due to the inadequate number of observations we have not attempted to use this information to estimate separate specifications for them.

${ }^{18}$ Systematic measurement error regarding self-reported height may occur. Persons who have higher wages may have higher self-confidence and, consequently, they could overstate their actual height. This error would imply that the estimates for self-reported height on labor market outcomes are downwardly biased.

${ }^{19}$ Capital income includes capital gains, rents, dividends, taxable interest payments, as well as income that an owner gets from a business he owns.

${ }^{20}$ These patterns are reported in the working paper version. 
${ }^{21}$ We use the terms 'wage effect' and 'earnings effect' interchangeably when the dependent variable is life-time earnings. Later, the results for employment confirm that the earnings effects arise mostly from wage differences rather than employment differences.

${ }^{22}$ Böckerman et al. (2010) have reported earlier the existence of a height premium in Finland, using the Health 2000 data set. With the same data, Johansson et al. (2009) document the wage penalty associated with various measures of obesity, including the measures that capture different aspects of body composition. Sarlio-Lähteenkorva et al. (2004) have also examined the effects of obesity on labor market outcomes in the Finnish context.

${ }^{23}$ The twin-difference estimate for the return to one additional year of education on life-time earnings for men is $19 \%$ (not reported in Table 3). The estimate for women is lower at $12 \%$. Because we use a measure for earnings as the dependent variable in Table 3, the earnings effects also include the employment effects. The effect of education on employment is nonnegligible despite the fact that average employment months are a crude measure for the difference in labor market participation for different education groups. For men one additional year of education increases average employment per year approximately $2 \%$. Our outcome is life-time earnings, not annual earnings. This implies that the magnitude of our estimates is not directly comparable to those reported in the earlier studies. Also, the estimates for the return to education are rather imprecise. For example, the lower bound of the $95 \%$ confidence interval for the point estimate (19\%) for men is $10 \%$.

${ }^{24}$ The results for employment that do not control for education are documented in the working paper version. These are similar to the employment results in Table 4.

${ }^{25}$ Silventoinen et al. (2004) observe that the association between body height and education is largely due to the correlation of the shared environmental factors affecting these two traits. 
${ }^{26}$ There is a large literature in psychology on the association between social skills and various labor market outcomes, including promotions and earnings (see Barrick and Mount, 1991).

27 Also Kortt and Leigh (2010, p. 75-76) find very little evidence that health affects the returns to height or weight. They control for four physical health dimensions that are physical functioning, role-physical, bodily pain and general health.

${ }^{28}$ The explanation based on health and physical strength may be more relevant in developing countries (cf. Case and Paxson 2008, p. 500).

${ }^{29}$ To compress the presentation of the additional results, in Table 7 and Table A2 we focus only on the most interesting specifications.

${ }^{30}$ The focus on capital income removes, for the most part, the effect of discrimination on hiring decisions, but discrimination by consumers against short persons may still have some impact on the amount of capital income. However, our capital income measure also contains income from financial investments where discrimination by consumers is not possible.

${ }^{31}$ We have also estimated the models for each year over the period 1990-2004. For men the correlation between the gender-specific unemployment rate and the annual earnings effects of height for the OLS estimate is 0.16 (p-value 0.58) and for the preferred IV estimate it is higher at 0.32 (p-value 0.24). For women the correlations are 0.30 (p-value 0.28 ) and 0.14 (pvalue 0.62), respectively. These correlations are all positive but not statistically significant. But the estimation period (1990-2004) is strongly dominated by the severe depression of the early 1990s and a slow recovery from that. This implies that the conclusions about the cyclical variation of the estimates for height (and BMI) are driven essentially by one depression. For men, the average OLS estimate of the height premium is 0.02 for the low 
unemployment period 1990-1991 and 0.03 for the high unemployment period 1992-2004. These means are statistically significantly different using a means test, with a p-value of 0.002. For women, these means are not statistically significantly different.

${ }^{32}$ Kortt and Leigh (2010, p. 77-79) provide a useful discussion of possible problems in instrumenting BMI. For example, BMI measures of other members of the same family may not be valid because of common, unobserved family effects. Note, however, that we use weight differences between twins, which removes such unobserved effects.

33 Cawley (2004) uses sibling BMI as an instrument for a person's own BMI and finds a negative causal effect of a person's own BMI on wages. 